\title{
The IDD and Its Impact on the Life Insurance Industry
}

\author{
Kyriaki Noussia
}

\section{Introduction}

Directive (EU) 2016/97 on Insurance Distribution of 20 January 2016, ('IDD”), aimed to harmonise national provisions concerning the distribution of insurance and reinsurance products and insurance-based investment products ("IBIPs") by insurance intermediaries, insurance companies, their employees, and ancillary insurance intermediaries in the European Union.

The initial date of the implementation of the IDD and the application of the corresponding Delegated Regulations was ultimately postponed to 1 October 2018, for the insurance firms, so as to allow the market the necessary time needed for it to adapt. In turn, the European Parliament substantiated this request for postponement by the need to give insurance undertakings and insurance distributors more time to better prepare for a correct and effective implementation of the Directive and to implement the necessary technical and organisational changes to comply with the Delegated Regulations. The IDD aimed to improve the regulation of retail insurance sales and distribution practices across the single European market and to bring greater transparency and improved, more comprehensible, information to consumers, so as to help people ensure that they buy products that suit their needs. It

The original version of this chapter was revised. A correction to this chapter can be found at https://doi.org/10.1007/978-3-030-52738-9_17

\footnotetext{
${ }^{1}$ Directive (EU) 2016/97 of the European Parliament and of the Council of 20 January 2016 on insurance distribution (recast), available at http://data.europa.eu/eli/dir/2016/97/oj.

K. Noussia $(\bowtie)$

University of Exeter, School of Law, Exeter, UK

e-mail: k.noussia@exeter.ac.uk 
serves as a minimum harmonisation Directive, meaning that Member States may "gold-plate" it, and, in doing so, impose higher standards and requirements, if they wish to do so.

Following the credit crunch of 2007/2008 lawmakers aimed at rebuilding the confidence of the investors into the financial markets. ${ }^{2}$ Hence, any post-crisis regulation has as its overarching aim the prevention of any regulatory arbitrage which could lead to incentives to set up products solely to circumvent more stringent standards. The levelling of the playing field has attracted insurance products, especially those relating to life insurance or financial ones. This attraction has been mirrored at EU level ${ }^{3}$ whereby Directive 2014/65/EU of 15 May 2014 on markets in financial instruments (MiFID II) ${ }^{4}$ repealed the previous Directive 2004/ 39/EC (MiFID). ${ }^{5}$ Recital 87 of MiFID II also outlined that in order to deliver consistent protection for retail clients and ensure a level playing field between similar products, it is important that IBIPs are subject to appropriate requirements and that any cross-sectorial inconsistencies which are detrimental to consumers are being addressed. To this effect, the IDD introduced some rules and principles contained in the final version of the MiFID II.

The IDD plays a significant role for the promotion of consumer protection within the distribution of insurance products across the EU, especially if one considers the fact that the MiFID II Directive does not cover the distribution of IBIPs. In particular, the IDD ensures a greater transparency of insurance distributors in relation to the price and costs of their products but also provides higher standards concerning product information and conduct of business ("COB") rules. In performing this function, the IDD provides many rules following the similar MiFID II rules. However, many differences still exist and pose a risk for segmentation or regulatory arbitrage. ${ }^{6}$ Moreover, while the MiFID II Directive aspired to a maximum harmonisation, the IDD expressly aimed at a minimum harmonisation, allowing Member States to impose stricter rules for the protection of the customers. ${ }^{7}$

\footnotetext{
${ }^{2} \mathrm{G}-20$ Leaders (2008) and Śliwiński and Marano (2020).

${ }^{3}$ Marano (2017) and Śliwiński and Marano (2020).

${ }^{4}$ Directive 2014/65/EU of the European Parliament and of the Council of 15 May 2014 on markets in financial instruments and amending Directive 2002/92/EC and Directive 2011/61/EU, available at http://data.europa.eu/eli/dir/2014/65/oj.

${ }^{5}$ Directive 2004/39/EC of the European Parliament and of the Council of 21 April 2004 on markets in financial instruments amending Council Directives 85/611/EEC and 93/6/EEC and Directive 2000/12/EC of the European Parliament and of the Council and repealing Council Directive 93/22/ EEC, available at http://data.europa.eu/eli/dir/2004/39/oj.

${ }^{6}$ Colaert (2015); Kern (2018), pp. 16-24.

${ }^{7}$ Recital 3 of the IDD.
} 
The IDD aimed explicitly to harmonise national provisions concerning Insurance $^{8}$ and Reinsurance ${ }^{9}$ Distribution across the Union, ${ }^{10}$ and targeted not only, as previously, insurance brokers or intermediaries, but several types of persons or institutions which distribute IBIPs to third parties, such as agents, "bancassurance" operators, insurance undertakings, travel agents and car rental companies. ${ }^{11}$ However, its overarching aim is that customers, regardless of the distribution channel, would benefit from the same level of protection and equal treatment. ${ }^{12}$ In particular, in line with the MiFID II regime for financial instruments and structured deposits, within the IDD the regime of customer protection is ensured by specific provisions concerning the conduct of business rules and product governance requirements. ${ }^{13}$

As the Member States of the European Union begun to fully enact and enforce the provisions of the IDD, we started slowly witnessing changes in how insurance products are marketed and sold across Europe. History tells us that no matter how clever and careful the drafters of a body of law are, no one can precisely predict all the impacts that a body of regulations will cause in any particular market. In line with the above realisation, the fact that the IDD is a "minimum harmonization" directive, means that Member States can keep their own regulations applicable to intermediaries, in effect, so long as there is no conflict with the IDD.

In effect, The IDD arose out of a desire to give insurance customers equal protection regardless of the type of distributor from which they obtained insurance. ${ }^{14}$ It seeks to level the playing field of protections for insurance customers by simplifying, consolidating, and expanding customer protections when needed. The IDD has the stated goal of focusing on "the area of the disclosure of information" to customers $^{15}$ and applies "to persons whose activity consists of providing insurance or reinsurance distribution services to third parties."16

The IDD aims at enhancing protections for customers and retail investors buying insurance products or insurance-based investment products. This purpose is in line

\footnotetext{
${ }^{8}$ 'Insurance distribution' is defined as the "activities of advising on, proposing, or carrying out other work preparatory to the conclusion of contracts of insurance, of concluding such contracts, or of assisting in the administration and performance of such contracts". See Article 1(1) IDD.

'Reinsurance distribution' is defined as the activities of advising on, proposing, or carrying out other work preparatory to the conclusion of contracts of reinsurance, of concluding such contracts, or of assisting in the administration and performance of such contracts, in particular in the event of a claim, including when carried out by a reinsurance undertaking without the intervention of a reinsurance intermediary. See Article 1(2) IDD.

${ }^{10}$ Recital 2 IDD.

${ }^{11}$ Recital 5 IDD; De Maesschalck (2017), pp. 63-65.

${ }^{12}$ Recital 6 IDD.

${ }^{13}$ Noussia and Siri (2019).

${ }^{14}$ Martinez and Marano (2020); Recital No 5 of the IDD highlights "agents, brokers and 'bancassurance' operators, insurance undertakings, travel agents and car rental companies" as examples of what a distributor is.

${ }^{15}$ See Recital No 6 of the IDD.

${ }^{16}$ See Recital No 11 of the IDD.
} 
with the main objective of insurance and reinsurance regulation and supervision in the European Union, which is the adequate protection of policyholders and beneficiaries, as stated by Recital No.16 of the Directive 2009/138/EC of the European Parliament and the Council of November 25, 2009 on the taking-up and pursuit of the business of insurance and reinsurance (Solvency II). The IDD seeks to achieve the goal of enhancing customer protection by ensuring greater transparency of insurance distribution with regard to the price and costs of insurance products, requiring better and more comprehensible product information, and improving conduct of business rules, with particular attention to advice.

\subsection{The Distributor's Remuneration}

Unlike the MiFID II Directive, which considerably restricted the possibility for firms providing the service of investment advice on an independent basis and the service of portfolio management to accept and retain fees, commissions or any monetary and non-monetary benefits from third parties, and particularly from issuers or product providers, the IDD generally accepts such remuneration in connection with the distribution of an IBIP as long as the payment of fees, commissions or any non-monetary benefit does not have a detrimental impact on the quality of the relevant service and does not impair the distributor's duty to act honestly, fairly and professionally in accordance with the customer's best interests.

The IDD applies to customers and is accompanied by a broad range of mandatory disclosures of fees and conflicts by insurance intermediaries to customers. In particular, the intermediary has to disclose whether, in relation to the insurance contract, it works on the basis of a fee, a commission of any kind, any other type of remuneration and any combination of the above. Furthermore, to avoid distortion of competition by encouraging insurers to sell directly to customers rather than via intermediaries in order to avoid information requirements, insurers are required to provide information to customers about the nature of the remuneration their employees receive for the sale of insurance products. ${ }^{17}$

Additionally, insurance distributors shall not make any arrangement by way of remuneration, sales targets, or otherwise that could provide an incentive to itself or its employees to recommend a particular insurance product to a customer when the insurance distributor could offer a different insurance product which would better meet the customer's needs. ${ }^{18}$

Additional disclosure requirements apply in the case of insurance-based investment products. Distributors must provide additional information detailing any cost of distribution that is not already included in the costs specified in the key information documents (KID) for packaged retail and insurance-based investment products.

\footnotetext{
${ }^{17}$ Martinez and Marano (2020).

${ }^{18}$ See Article 17(3) of IDD.
} 
This enables the customer to understand the cumulative effect that those aggregate costs have on the return on investment. ${ }^{19}$

The adoption of criteria based on the MiFID II Directive seemed like the best solution in many respects, i.e. firstly because it was considered as striking the appropriate balance between the interests of insurance distributors and those of their customers and because it was considered as enabling the necessary flexibility at National Competent Authority ("NCA") level. ${ }^{20}$

\subsection{Distributors' Liabilities: Life Insurance}

\subsubsection{Scope of Distributors: Dual Responsibilities}

The first impact of the IDD $^{21}$ directly follows from the new definition of the so-called "distributors". This term deliberately differs from the reference to the sole "intermediaries" mentioned in the previous Directive 2002/92/EC on insurance mediation ("IMD"). ${ }^{22}$ "Insurance distributor" is a term referring to any insurance intermediary, ancillary insurance intermediary and insurance undertaking, encompassing a large variety of persons or institutions, including the traditional agents, brokers and "bancassurance" operators, insurance companies, are subject to "equality of treatment" (i.e. same level of duties, obligations and liabilities) which are considered necessary so as to ensure customer protection. In short, anybody involved with insurance distribution, especially advising on, proposing, carrying out preparatory work to the conclusion of insurance or concluding insurance contracts, falls within the scope of IDD.

Because one of the objectives of the IDD was to guarantee an effective protection of customers across all financial sectors, and to guarantee that the same level of protection applies regardless of the channel through which customers buy an insurance product, ${ }^{23}$ this explains why the IDD covers the distribution of not only non-life and life products, but also reinsurance products, and IBIPs. This also explains why the IDD applies to insurance distributors, when the previous Directive on insurance mediation, i.e. IMD, applied only to insurance intermediaries. Hence, based on the new definition of the insurance distributor, the IDD encompasses a larger number of firms than the IMD. This level playing field is considered a guarantee for customers to benefit from the same level of protection. In practice, however, it may lead to

\footnotetext{
${ }^{19}$ See Article 29 of IDD.

${ }^{20}$ EIOPA (2017).

${ }^{21}$ Directive (EU) 2016/97, op.cit.

${ }^{22}$ Directive 2002/92/EC of the European Parliament and of the Council of 9 December 2002 on insurance mediation, available at http://data.europa.eu/eli/dir/2002/92/oj.

${ }^{23}$ Commission 2012 staff working document executive summary of the impact assessment accompanying the document proposal for a Directive of the European Parliament and of the Council on insurance mediation.
} 
situations of co-liability among the various types of distributors at stake where national legislations had operated a "clear-cut" in terms of liability before.

The IDD applies to insurance intermediaries, of course, but also to direct writers, i.e. to insurance undertakings which sell insurance products directly. The IDD, unlike the IMD, also expressly applies to certain activities conducted through price comparison websites. The IDD also applies to persons whose activity consists of the provision of information on one or more contracts of insurance in response to criteria selected by the customer, via a website or other media or of the provision of a ranking of insurance products or a discount on the price of an insurance contract, when the customer is able to directly or indirectly conclude an insurance contract at the end of the process. ${ }^{24}$

With regards to distribution agreements, beyond the respective obligations laid down in Regulation (EU) 2017/2358 ${ }^{25}$ with regard to the terms of the collaboration agreement between the insurance intermediary and the insurance company, such distribution agreements should be carefully reviewed on both sides, i.e. from the side of the intermediary and from the side of the insurance company, in order to precisely clarify their respective role, anticipate potential risk scenarios and achieve a good balance, especially as to their respective liability.

With regards to IBIPs, and on top of PRIIP's Regulation EU/1286/2014, ${ }^{26}$ as per the IDD, the distribution of IBIPs generates a full range of additional obligations for the distributors: (a) specific professional and organisational requirements must be abided by (art. 10, IDD). Buying an IBIP implies a risk and investors should be able to rely on the information and quality assessment provided. Insurance intermediaries and insurance undertakings that advise on, or sell, IBIPs to retail customers are to possess an appropriate level of knowledge and competence in relation to the products offered and their employees should be given adequate time and resources to be able to exhaustively inform the customers; (b) specific information standards (art. $29 \&$ art. 30 of IDD and Regulation (EU) 2017/2358) aimed at addressing the investment embedded in IBIPs shall apply and include that the provision of appropriate information and the requirements for advice need to be suitable; (c) restrictions on remuneration (art. $28 \&$ art. 29 of IDD and Regulation (EU) 2017/2359 ${ }^{27}$ ) apply. The payment of remuneration (fee, commission, non-monetary benefits) in

\footnotetext{
${ }^{24}$ Article 1.2., Article 10.2. of the IDD; De Maesschalck (2017).

${ }^{25}$ Commission Delegated Regulation (EU) 2017/2358 of 21 September 2017 supplementing Directive (EU) 2016/97 of the European Parliament and of the Council with regard to product oversight and governance requirements for insurance undertakings and insurance distributors, available at http://data.europa.eu/eli/reg_del/2017/2358/oj.

${ }^{26}$ Regulation (EU) No 1286/2014 of the European Parliament and of the Council of 26 November 2014 on key information documents for packaged retail and insurance-based investment products (PRIIPs), available at http://data.europa.eu/eli/reg/2014/1286/oj.

${ }^{27}$ Commission Delegated Regulation (EU) 2017/2359 of 21 September 2017 supplementing Directive (EU) 2016/97 of the European Parliament and of the Council with regard to information requirements and conduct of business rules applicable to the distribution of insurance-based investment products, available at http://data.europa.eu/eli/reg_del/2017/2359/oj.
} 
connection with the distribution of IBIPs should not have a detrimental impact on the quality of the relevant service. In order to fulfil this condition satisfactorily the distributor should develop, adopt and regularly review policies and procedures relating to conflict of interests and ensure that the customer is adequately informed about fees, commissions or benefits. When advice is provided to the customer the information on (1) all costs and related charges must be disclosed, as well as (2) information relating to the distribution of the product, (3) including the cost of advice.

\subsubsection{Impact on International Activities (Free Passporting Service ('FPS"))}

In spite of the willingness to establish a single internal market barriers to the taking up and pursuit of the activities of insurance and reinsurance intermediaries in the internal market remained up to the introduction of the IMD, and the inability for the latter to operate freely throughout the Community hindered the proper functioning of the single market in insurance. The IMD introduced a single passport for insurance intermediaries: it provided a registration system for all insurance intermediaries based on a whole range of binding professional requirements aimed at enhancing the protection of consumers in insurance matters and at facilitating cross-border activities. Registered insurance intermediaries will be allowed to take up and pursue the activity of insurance mediation within the EU by means of both freedom of establishment and of services $^{28}$ after going through a notification procedure. ${ }^{29}$

For the first time the IDD specifies in a very clear manner at several places that the stricter requirements of a Member State have also to be complied with, by insurance intermediaries operating under the freedom to provide services. Under the regime of the IMD there was no clarity about the national law governing the duty to inform or advise the client living abroad when the insurance intermediary was active form his home country through the free "passporting" service ("FPS").

The IDD has a wider scope than the IMD and applies to all insurance distributors, including insurance undertakings. However, they do not have to register ${ }^{30}$ under the $^{-}$ IDD and their passporting rights remain governed by the relevant domestic provisions implementing the Solvency II Directive. The IDD applies to ancillary intermediaries. ${ }^{31}$ Registered ancillary insurance intermediaries under the IDD will be allowed to operate under freedom of service and/or establishment.

Under the IMD, once the intermediary had informed its home Member State of its intention to operate cross-border in one or more Member States under freedom of service and/or establishment for the first time, the home Member State authority was

\footnotetext{
${ }^{28}$ Article 3, IMD.

${ }^{29}$ Article 6, IMD.

${ }^{30}$ Article 3.1 (2) of the IDD.

${ }^{31}$ Ancillary intermediaries are defined under Article 2(4) of the IDD.
} 
required, within 1 month of receiving the information, to notify the competent authorities of the relevant host Member States. It had also to advise the applicant intermediary that it had done this. The intermediary could only commence its activities 1 month after the date of notification. The IMD allowed an exemption for the host Member State to be notified. In practice, in cases where Member States chose to be notified - and they were a majority — this meant that an intermediary had to wait up to 2 months before being allowed to operate cross-borders. The approach of other Directives was more favourable: under MiFID for example an investment firm could go cross-border immediately upon notification by home to host Member States of the firm's intention to passport under freedom of service. The IDD, in two separate articles (Articles 4 and 6), details different notification requirements for freedom of service and/or establishment activities.

Like the IMD, the IDD requires the national registers to indicate the Member States in which "their" intermediaries conduct business under freedom of service or establishment activities. The IDD ${ }^{32}$ also requires EIOPA to establish, publish on its website and keep up to date a single electronic register of intermediaries operating cross-border in their respective countries. ${ }^{33}$ Under the IMD, the only power clearly given to host Member States over insurance intermediaries operating under freedom of service and/or establishment activities in their markets, was the one to adopt specific legal provisions to protect the general good. ${ }^{34}$ The IMD did not, however, clearly divide competences between home and host member State competent authorities. The IDD clearly divides the oversight powers between the home and host Member States competent authorities over insurance intermediaries who are "passporting" in the EU and makes clear that in case of intermediaries' FOS activities, the home Member State competent authority will be responsible for ensuring compliance with all IDD requirements. The IDD goes even further and introduces new powers for host Member States to help them preventing the circumvention of their rules by insurance intermediaries. ${ }^{35}$

Intermediaries will also need to particularly focus on these national rules in the context of the information provided to policyholders, i.e. in respect of advice given and disclosure of remuneration schemes. Interestingly enough, in the context of "national law governing the situation", the IDD considers that stricter national provisions of the customer's habitual residence are the relevant ones. According to IDD (article 22 (2)), the provision of advice is mandatory if the customer's country of habitual residence so foresees. This may create inconsistent legal situations and requires anticipation measures by the stakeholders as Directive Solvency II, ${ }^{36}$ in its

\footnotetext{
${ }^{32}$ Article 3(4), IDD.

${ }^{33}$ Audigier (2020).

${ }^{34}$ Article 6.3 and article 8.4, IMD.

${ }^{35}$ Article 9, IDD.

${ }^{36}$ Directive 2009/138/EC of the European Parliament and of the Council of 25 November 2009 on the taking-up and pursuit of the business of Insurance and Reinsurance (Solvency II) http://data. europa.eu/eli/dir/2009/138/oj.
} 
article 178 on applicable law, expressly refers to the alternative provided for in Regulation Rome I, ${ }^{37}$ namely the possibility for the policyholder to opt for the law of his nationality. Because the IDD aims at a so-called minimum harmonisation and because for the first time in the EU legislative framework, insurance intermediaries, are expressly reminded of their obligation to follow the stricter requirements of their policyholders' country of residence, ${ }^{38}$ insurance intermediaries and employees of insurance undertakings will also need to comply with continuing professional training and development requirements_-including knowledge of financial risks, of the insurance market, of applicable laws governing the distribution of insurance products such as consumer protection law and relevant tax law, of assessing customer needs, etc.. No doubt that such implementation may appear at first glance as too wide and burdensome, but it should be seen as a unique opportunity for all entities involved to (re-)negotiate distribution agreements, especially brokerage agreements, but also financial agreements such as asset management agreements, in order to achieve a good balance of liabilities between the professionals involved, to review risk management options and to look for sustainable business alternatives. In addition, the Regulations supplementing the IDD do not involve transposition measures. The automatic result is that distributors have had to directly abide by their scope of obligations as early as October 2018. This, at least, left the door open for maximum harmonisation of operational processes and adequate internal and external advice.

\subsection{Inducements}

According to the IDD, the insurance intermediary should inform the client whether, in relation to the insurance contract, any inducement, ${ }^{39}$ i.e. any fee, commission or non-monetary benefit paid or provided by any party except the customer, is paid. The payment of inducements is only allowed if it '(a) does not have a detrimental impact on the quality of the relevant service to the customer, and (b) does not impair compliance with the insurance intermediary's or insurance undertaking's duty to act honestly, fairly and professionally in accordance with the best interests of its customers'. ${ }^{40}$ This seems a less stringent discipline compared to that provided in MiFID II, which imposes specific bans and strict limitations to fees and commission

\footnotetext{
${ }^{37}$ Regulation (EC) No 593/2008 of the European Parliament and of the Council of 17 June 2008 on the law applicable to contractual obligations (Rome I) http://data.europa.eu/eli/reg/2008/593/oj.

${ }^{38}$ These stricter national rules will notably impact pre-contractual information duties, the type of advice to be given, the product documentation, authorised remuneration schemes and in particular the incentives gathered from underlying investment vehicles.

${ }^{39}$ Article 19(1)(e) IDD.

${ }^{40}$ Article 29(2) IDD.
} 
paid in connection to financial advice. ${ }^{41}$ All rebates are relevant, irrespective of their origin.

The insurance intermediary or insurance undertaking is required to consider the amount of inducement being paid in comparison to the value of the product or service being provided. Regardless of whether a personal recommendation is provided, a rebate should be assessed in accordance with Article 29(2), IDD. ${ }^{42}$

\section{The Need for Regulation: Specific Professional and Organizational Requirements}

Since the foundation of the European Community in 1957, many Directives, targeting a more integrated financial market and a harmonized approach, were issued. ${ }^{43}$ In the past 25-30 years the financial market have undergone a deregulation process through the European Union's Third Generation Insurance Directive which was implemented in 1994. Creating a single European insurance market with a better diversification and a strong competition should have a positive effect on the choice of the policyholders with a variety of insurance products. ${ }^{44}$

The First Life Insurance Directive $1979 / 267^{45}$ was codified by Directive 2002/ $83^{46}$ and then repealed by Directive $2009 / 138^{47}$ (Solvency II). Directive 2004/39 on markets in financial instruments ("MiFID") was followed by Directive 2014/65 ("MiFID II"). Directive 2002/92 on Insurance Mediation ("IMD") was the first Directive to impose specific obligations for the insurer and the distributor of investment products. The IMD was replaced by the IDD and was further exemplified the rules on the sale of investment products contained in MiFID II and in Regulation $1286 / 2014$ on packaged retail and insurance-based investment products (PRIIPs Regulation). $^{48}$

The IDD plays a significant role for the promotion of consumer protection within the distribution of insurance products across the EU, especially if considered that MiFID II does not covers the distribution of insurance-based products. In particular,

\footnotetext{
${ }^{41}$ Art 24(7) and (9) of MiFID II.

${ }^{42}$ EIOPA Q and A on Regulation (2018), No. 1635.

${ }^{43}$ Cummins et al. (2017), p. 67; Petsch (2019).

${ }^{44}$ Cummins et al. (2017), p. 66; Petsch (2019).

${ }^{45}$ First Council Directive 1979/267 1979 on the coordination of laws, regulations and administrative provisions relating to the taking up and pursuit of the business of direct life assurance Official Journal L 063, 13/03/1979 P. 0001-0018.

${ }^{46}$ Directive 2002/83 on life insurance, OJ L 345, 19.12.2002, p. 1-51.

${ }^{47}$ Directive 2009/138 (Solvency II), OJ L 335, 17.12.2009.

${ }^{48}$ Regulation (EU) No 1286/2014 of the European Parliament and of the Council of 26 November 2014 on key information documents for packaged retail and insurance-based investment products (PRIIPS) http://data.europa.eu/eli/reg/2014/1286/oj; Noussia and Siri (2019).
} 
the IDD ensures a greater transparency of insurance distributors in relation to the price and costs of their products but also provides higher standards concerning product information and conduct of business (COB) rules. ${ }^{49}$

Some changes already began with the consideration of Solvency $\mathrm{II}^{50}$ and a further significant transformation of the supervision of financial institutions occurred during the financial crisis in 2007 and 2008. ${ }^{51}$ From then on, the European Commission is constantly working for a harmonization of the regulatory framework across the EU member countries. This implies implementing standards to react to a rapidly changing market. ${ }^{52}$ Hence, the IDD was developed as a consequence of regulatory changes and in order to strengthen the consumer protection and establish a competitive and harmonized landscape of the insurance business in the EU. Even if the insurance business is traditionally seen as a stable financial sector, the liquidity liabilities within the banking industry increases the risk of contagious runs, and this also relates to partnerships and "bancassurance" and the subsequent cross-selling strategy, that is implied, which has initiated the development of complex risk management products and which also represents a challenge for the regulator to understand and evaluate them. ${ }^{53}$

Insurance companies offer products which are similar to saving products offered from banks. In doing so, they have, in the last years, transformed and positioned themselves as major actors within the financial market. New financial innovations modified the portfolios and increased the complexity of financial products. The liquidity risk and the systemic risk became higher. Life insurance products extended and became more similar to banking products. The new options within these products raised the liquidity of the liabilities. Because of these changes, there is now a clear difference to traditional insurance products, which has also revealed new levels of exposure. ${ }^{54}$ In general, however, insurance companies have more liquid assets than banks, such as bonds, loans, real estate and equities, hence a lower liquidity risk.

The above realisations apart, the need to protect the interests of the policyholders and the overall stability of the financial system emphasizes the necessity of transparency through regulation, as the principle objective of supervision is the protection of the policyholder. Policyholders don't know how their paid premiums are used. Policyholders are as well not capable of evaluating the financial stability of the insurance company. Regulations should guarantee that the insurance company meets its obligations and protects the policyholder. ${ }^{55}$ Any regulatory framework within the prudential authority needs to support the policyholders. Another reason for

\footnotetext{
${ }^{49}$ Noussia and Siri (2019).

${ }^{50}$ Cummins et al. (2017), p. 67; Petsch (2019).

${ }^{51}$ Doff (2008), pp. 196-198; Petsch (2019).

${ }^{52}$ Eling et al. (2007), p. 69; Petsch (2019).

${ }^{53}$ Das et al. (2003) and Petsch (2019).

${ }^{54}$ Lorent (2008) and Petsch (2019).

${ }^{55}$ OECD (1998), available at: http://www.oecd.org/regreform/sectors/1920099.pdf (04 April 2019).
} 
prudential regulations is that claimholders will always demand the payment of their claims. A regulatory structure matters when the system suffers from agency problems and information asymmetries. Therefore, an external regulatory framework needs to be introduced. This structure creates synergies and is more efficient when it comes to functions and expertise. Additionally, it prevents regulatory gaps and duplicated control functions, while setting clear responsibilities and increasing the commitment of the supervisor. ${ }^{56}$ Pertinent to the above need, the IMD information and conduct of business requirements were significantly amended by the requirements of Chapter V of the IDD. The stricter selling practices introduced, took the MiFID II Directive into account to ensure cross-sector consistency. This means that customers are now afforded equivalent levels of protection under the two regimes. Firms involved in the distribution of IBIPs have to comply with specific requirements set out in Chapter VI in addition to the Chapter V requirements in recognition of the fact that IBIPs are higher-risk products.

Hence, by the end of 2018 the IDD was fully implemented by all EU member states with the intention to harmonize the insurance business in the EU, provide the right incentives for sales agents and protect the policyholders via solving issues of transparency, information asymmetry and agency problems, and by creating incentives, a representation of the policyholder and the inversion of the production cycle. $^{57}$

The IDD has three lists of subjects that it covers: general insurance, life insurance and insurance-based investment products. There is no further guidance, other than these three lists, published by the EU authorities and it is up to firms to interpret what the lists mean. For life insurance, the requirements are: minimum necessary knowledge of IBIPs, including terms and conditions and net premiums and, where applicable, guaranteed and non-guaranteed benefits; minimum necessary knowledge of advantages and disadvantages of different investment options for policyholders; minimum necessary knowledge of financial risks borne by policyholders; minimum necessary knowledge of policies covering life risks and other savings products; minimum necessary knowledge of organisation and benefits guaranteed by the pension system; minimum necessary knowledge of applicable laws governing the distribution of insurance products, such as consumer protection law and relevant tax law; minimum necessary knowledge of the insurance market and of the saving products market; minimum necessary knowledge of complaints handling; minimum necessary knowledge of assessing customer needs; conflicts of interest management; minimum necessary knowledge of business ethics standards; minimum necessary financial competency. For IBIPs, the requirements are: minimum necessary knowledge of policies including terms, conditions, the guaranteed benefits and, where applicable, ancillary risks; minimum necessary knowledge of organisation and benefits guaranteed by the pension system of the relevant Member State; knowledge of applicable insurance contract law, consumer protection law, data protection law,

\footnotetext{
${ }^{56}$ Gaganis and Pasiouras (2013).

${ }^{57}$ Petsch (2019).
} 
data protection law, anti-money laundering law and, where applicable, relevant tax law and relevant social and labour law; minimum necessary knowledge of the insurance and other relevant financial services markets; minimum necessary knowledge of complaints handling; minimum necessary knowledge of assessing consumer needs; conflicts of interest management; minimum necessary knowledge of business ethics standards; and minimum necessary financial competency. ${ }^{58}$

\section{Special Requirements Relating to Information, Advice, Remuneration}

\subsection{Information Requirement and the Duty to Act in the Customers' Best Interests}

Ensuring the best interests of the customer is one of the motives of the IDD $^{59}$ and reflects the intention behind many of the obligations imposed on insurance distributors.

The concept of acting in the best interest of the customer adopted in the IDD Directive is not new and it reflects the obligations imposed under the MiFID Directive. The MiFID requirements for acting in the best interests of the customer focus primarily on customer information obligations in relation to the investment company providing the services, the financial instruments and the proposed investment strategies, which should include appropriate guidance and warnings about the risk associated with investment in such instruments or in relation to particular investment strategies, as well as information about the executors, costs and related fees. The aforementioned information should be structured in such a way that the customers or potential customers are able to understand the nature and risks of the investment service. ${ }^{60}$

The principle of the customer's best interest is also the core of the MiFID II Directive, where, as per Recital 71, investment companies should therefore understand the characteristics of the financial instruments they offer or recommend and develop effective strategies and arrangements to identify and review the categories of customers to whom products are to be delivered and services are to be provided. Member States should ensure that investment companies creating financial instruments guarantee that those products are developed in order to satisfy the specific needs of the target market, that they take reasonable steps to ensure that financial instruments are distributed within a specific target market, and that they periodically

\footnotetext{
${ }^{58}$ CII: Policy Briefing: Implementing the Insurance Distribution Directive: key provisions and analysis. March 2018, available at https://www.cii.co.uk/media/7775189/cii-policy-briefing-iddimplementation-22march2018.pdf.

${ }^{59}$ Malinowska (2018), p. 57.

${ }^{60}$ Paś (2020).
} 
review the target market identification data and the performance of the products offered. Investment companies should also have adequate arrangements in place to obtain and understand relevant information regarding the product approval process, including the specific target market and the characteristics of the product they are offering or recommending. ${ }^{61}$

The IDD introduces a new obligation on insurance distributors to always act honestly, fairly and professionally, in accordance with the best interests of their customers (Article 17(1), IDD). One way in which insurance distributors are to comply with Article 17(1) is to ensure that they are not remunerated, and that they do not remunerate or assess the performance of their employees, in a way that conflicts with their duty to act in their customers' best interests (Article 17(3), IDD). In particular, the IDD explains that remuneration arrangements and sales targets should not provide an incentive to recommend a particular insurance product to a customer when a different product could be offered that would better meet the customer's needs (Article 17(3), IDD). The term "remuneration" is defined widely in Article 2 (1)(9) of the IDD to mean any commission, fee, charge or other payment, including an economic benefit of any kind, or any other financial or non-financial advantage or incentive offered or given in respect of insurance distribution activities.

All information related to the IDD, including marketing communications, addressed by an insurance distributor to customers or potential customers must be fair, clear and not misleading (Article 17(2), IDD). Article 17(2) states that its provisions are without prejudice to the Unfair Commercial Practices Directive (2005/29/EC) (UCPD). ${ }^{62}$ Article 18 of the IDD provides for the obligation for general information. In good time before the conclusion of an insurance contract, an insurance intermediary or insurance undertaking must disclose to customers: (a) its identity and address, and the fact that it is an insurance intermediary or insurance undertaking, as appropriate; (b) whether it provides advice about the insurance products sold; (c) the procedures enabling customers and other interested parties to register complaints as referred to in Article 14; (d) the out-of-court complaint and redress procedures referred to in Article 15. In addition to the information listed above, an insurance intermediary must disclose to customers the register in which it has been included and the means for verifying that it has been registered and whether it is representing the customer or is acting for and on behalf of an insurance undertaking. In accordance with Article 19 of the IDD, there is a need for disclosing the nature of the remuneration received relating to the insurance contract, i.e. whether, in relation to the insurance contract, it works on the basis of a fee, i.e. the remuneration paid directly by the customer, or on the basis of a commission of any kind, i.e. the remuneration included in the insurance premium, or on the basis of other types of remuneration, including an economic benefit of any kind offered or given in connection with the insurance contract, or on the basis of a combination of any type of remuneration set out above. Where the fee is payable

\footnotetext{
${ }^{61}$ Paś (2020).

${ }^{62}$ Unfair Commercial Practices Directive (2005/29/EC) (UCPD).
} 
directly by the customer, there is a need to disclose the amount of the fee or, where this is not possible, the method for calculating it. Also there is an obligation of disclosures for any payments made by the customer under the insurance contract after its conclusion, other than ongoing premiums and scheduled payments. Hence, an insurance undertaking need only communicate, in good time before the conclusion of an insurance contract, to its customers, the nature of the remuneration received by its employees relating to the insurance contract and any disclosures for any payments made by the customer under the insurance contract after its conclusion, other than ongoing premiums and scheduled payments.

As per the IDD, all information addressed by the insurance distributor to customers or potential customers should be "fair, clear and not misleading". 63 Articles 18 to 24 , and 29 address the content, as well as the form and procedures that insurance distributors should perform in the disclosure of information to the client. First of all, before the conclusion of an insurance contract the insurance intermediary and undertaking should disclose: (i) its identity and address and that it is an insurance intermediary or undertaking; (ii) whether it provides advice about the insurance products sold; (iii) the procedures enabling customers and other interested parties to register complaints about insurance intermediaries and the out-of-court complaint and redress procedures. ${ }^{64}$ Before the conclusion of the contract, the insurance distributor should specify the demands and needs of the customer, provide the customer with objective information about the insurance product in an understandable form, but also ensure that the contract proposed is consistent with the client's demands and needs. ${ }^{65}$

Recital 41 to the IDD explains that these disclosure obligations have been imposed on insurance undertakings to avoid the distortion of competition. Otherwise, insurance undertakings would have an advantage of avoiding disclosure obligations by selling direct to customers, rather than through intermediaries. The Commission's original IDD legislative proposal included more detailed and onerous remuneration disclosure provisions for intermediaries. However, these proved very contentious and were removed from the agreed text during the EU legislative process.

\subsection{Advice Requirement}

Where advice is provided before a specific insurance contract is concluded, an insurance distributor must provide the customer with a personalised recommendation (Article 20(1), IDD). Recital 45 to the IDD explains that this is in addition to specifying the customer's demands and needs. The personalised recommendation

\footnotetext{
${ }^{63}$ Article 17(2) IDD and Article 24(3) MiFID II.

${ }^{64}$ Article 18 IDD.

${ }^{65}$ Art 20 (1) IDD.
} 
should explain why a particular product would best meet the customer's demands and needs. The details referred to in Article 20(1) IDD are to be adjusted according to both the complexity of the insurance product being proposed and the type of customer (Article 20(2), IDD). When an insurance intermediary informs a customer that it provides advice on the basis of a "fair and personal analysis", it must give advice on the basis of an analysis of a sufficiently large number of insurance contracts available on the market. This will enable the intermediary to make a personal recommendation on which insurance contract would be adequate to meet the customer's needs (Article 20(3), IDD). In the event the insurance intermediary gives its advice on the basis of a fair and personal analysis, it should advise on the basis of an analysis of a sufficiently large number of insurance contracts available on the market. ${ }^{66}$ Moreover, the insurance intermediary should communicate the register in which it has been included and the means for verifying that it has been registered and whether it is representing the customer or it is acting for and on behalf of the insurance undertaking. ${ }^{67}$

The insurance intermediary should also provide information concerning potential conflict of interests, such as whether it has a holding, direct or indirect, representing $10 \%$ or more of the voting rights or of the capital in a given insurance undertaking, or whether a given insurance undertaking or parent undertaking of a given insurance undertaking has a holding, direct or indirect, representing $10 \%$ or more of the voting rights or of the capital in the insurance intermediary. ${ }^{68}$ Similarly, in relation to the contracts proposed or advised upon, it should inform whether: (i) it gives advice on the basis of a fair and personal analysis; (ii) it is under a contractual obligation to conduct insurance distribution business exclusively with one or more insurance undertakings; or (iii) it is not under a contractual obligation to conduct insurance distribution business exclusively with one or more insurance undertakings and does not give advice on the basis of a fair and personal analysis. ${ }^{69}$ Information concerning all costs and related charges should be promptly disclosed to the customers, to allow them to understand the overall cost as well as the cumulative effect on the return on the investment. ${ }^{70}$

In assessing whether the number of contracts and providers considered by an insurance intermediary is sufficiently large to constitute a fair and personal analysis, Recital 47 to the IDD explains that appropriate consideration should be given to the customer's needs, the number of providers in the market, the market share of those providers, the number of relevant insurance products available from each provider, the features of those products. The Recital goes on to state that the IDD should not prevent member states from requiring insurance intermediaries that wish to give

\footnotetext{
${ }^{66}$ Article 20(3) IDD.

${ }^{67}$ Article 18 (a) IDD.

${ }^{68}$ Article 19 (1) (a-b) IDD.

${ }^{69}$ Article 19(1)(c) IDD.

${ }^{70}$ Article 29(1) IDD.
} 
advice on the basis of a fair and personal analysis to do so on an analysis of all the insurance contracts each intermediary distributes.

\subsection{Exemptions from Information Requirements}

Article 22(1) of the IDD explains that the information referred to in Articles 18, 19 and 20 does not need to be provided when an insurance distributor carries out distribution activities relating to the insurance of large risks. In addition, member states may decide that the information relating to insurance-based investment products referred to in Articles 29 and 30 does not need to be provided to professional clients (Article 22(1), IDD).

\subsection{Stricter Information Provisions}

The $\operatorname{IDD}^{71}$ is a minimum harmonisation directive meaning that member states have the express option of maintaining or adopting stricter national provisions in a number of key areas, including in relation to the $\mathrm{IDD}^{72}$ information provisions. Under Article 22(2) of the IDD, member states are allowed to gold plate the Chapter $\mathrm{V}$ information requirements provided the national provisions comply with EU law. In particular, member states may: (a) make the provision of advice referred to in Article 20(1) mandatory for the sales of any insurance products, or for certain types of insurance product (Article 22(2), IDD). In these cases, insurance distributors, including those exercising the free "passporting" service option, must comply with the stricter national provisions when concluding insurance contracts with customers who have their habitual residence or establishment in that member state, and limit or prohibit the acceptance or receipt of fees, commissions or other monetary or non-monetary benefits paid or provided to insurance distributors by any third party or a person acting on behalf of a third party relating to the distribution of insurance products (Article 22(3), IDD).

Any member state that proposes to apply and applies provisions in addition to those set out in the IDD must ensure that the administrative burden stemming from these provisions is proportionate with regard to consumer protection, and remains limited (Recital 52, IDD). Any member state that decides to exercise the discretion available under Article 22(2) must notify the Commission and EIOPA of its stricter national provisions (Article 22(2), IDD). To ensure a high level of transparency, EIOPA must ensure that the information it receives relating to national provisions is also communicated to customers, as well as insurance and reinsurance distributors

\footnotetext{
${ }^{71}$ Directive (EU) 2016/97, op. cit.

${ }^{72}$ Directive (EU) 2016/97, op. cit.
} 
(Article 22(4), IDD). Member states must also ensure that their National Competent Authorities (NCAs) publish information about whether and how the member state has chosen to apply the stricter provisions (Article 22(2), IDD).

\subsection{Information Conditions}

Under Article 23(1) of the IDD, all pre-contract information to be provided in accordance with Articles 18, 19, 20 and 29 must be communicated to customers on paper; in a clear and accurate manner, comprehensible to the customer; in an official language of the member state in which the risk is situated or the member state of the commitment, or in any other language agreed by the parties; free of charge.

However, under Article 23(2) to (6), instead of providing this information to the customer on paper, it may be provided either: (a) using a durable medium other than paper, where the use of the durable medium is appropriate in the context of the business conducted between the insurance distributor and the customer; the customer has been given the choice between information on paper and on a durable medium, and has chosen the durable medium; and a paper copy of the information is provided to the customer on request and free of charge; or (b) by means of a website, if it is addressed personally to the customer, where the provision of the information by means of a website is appropriate in the context of the business conducted between the insurance distributor and the customer and it is considered appropriate if there is evidence that the customer has regular access to the internet, such as for example, if there is evidence that the customer has an email address; where the customer has consented to the information being provided by means of a website; where the customer has been notified electronically of the website's address, and the place on the website where the information can be accessed; where the information remains accessible on the website for such a period of time as the customer may reasonably need to consult it; and where a paper copy of the information is provided to the customer on request and free of charge. In the case of telephone sales, the pre-contract information given to the customer, including the Insurance Product Information Document ("IPID"), must be provided in accordance with EU distance marketing requirements. Moreover, even if the customer has chosen to obtain prior information on a durable medium other than paper, the information must be provided by the insurance distributor to the customer in accordance with Article 23(1) or (2) immediately after the conclusion of the insurance contract (Article 23(7), IDD).

\subsection{New Information Requirements}

For the sake of better consumer protection, insurance distributors will have to act honestly, fairly and professionally in accordance with the best interests of their customers. In particular, they cannot make any arrangements by way of 
remuneration or sales target that could provide an incentive to recommend a particular product to a customer when they could offer a different product that would meet the customer's needs better.

Regarding IBIPs, there is no ban on commission or fees introduced in the IDD. This situation should be welcomed as every intermediary has the right to be fairly remunerated for his or her services. The IDD however, requires from member states, in all cases of packaging, to ensure that an insurance distributor specifies the demands and needs of the customer in relation to the insurance products that form part of the overall package or the same agreement. The IDD explicitly recognises the differences between IBIPs and investment products and that IDD is the place to regulate them (Recital 10), but at the same time indicates that there is need for alignment with MiFID II and that, due to their specific character, there is need for a separate chapter on IBIPs (Recital 56).

Intermediaries and undertakings have to make (proportionate) arrangements to prevent conflicts of interest from adversely affecting the interests of their customers and must take steps to identify conflicts of interest.

Information regarding the distribution and all costs and related charges has to be provided in good time, before the conclusion of the contract. Where the MiFID II Directive requires benefits to enhance the quality of the service to the client, ${ }^{73}$ and not against the criteria to act honestly, fairly, professionally and in the best interests of the client, the IDD allows them, if there is no detrimental impact on the quality of the service and it is not against the criteria to act honestly, fairly, professionally and in accordance with the best interests of its customers. In addition, the IDD explicitly foresees the possibility for member states to go beyond (e.g. prohibition of commissions, return to the client).

\subsection{Conflict of Interest}

The IDD and its delegated regulation ${ }^{74}$ follow the MiFID II Directive provisions and those of its Delegated Regulation. ${ }^{75}$ Article 23 of MiFID II, and article 28 of the IDD

\footnotetext{
${ }^{73}$ Commission 2012 staff working document executive summary of the impact assessment accompanying the document proposal for a Directive of the European Parliament and of the Council on insurance mediation; Directive 2014/65/EU of the European Parliament and of the Council of 15 May 2014 on markets in financial instruments and amending Directive 2002/92/EC and Directive 2011/61/EU http://data.europa.eu/eli/dir/2014/65/oj.

${ }^{74}$ Articles 3-7 of the Commission Delegated Regulation (EU) 2017/2359 of 21 September 2017 supplementing Directive (EU) 2016/97 of the European Parliament and of the Council with regard to information requirements and conduct of business rules applicable to the distribution of insurance-based investment products, http://data.europa.eu/eli/reg_del/2017/2359/oj.

${ }^{75}$ Commission Delegated Regulation (EU) 2017/565. See also the Explanatory Memorandum, Commission Delegated Regulation (EU) 2017/2359, p. 3.
} 
does not define or prohibit conflicts of interest. However, in the relevant Delegated Regulation ${ }^{76}$ we find provisions specifying certain situations which should be taken into account in the assessment of conflict of interest, ${ }^{77}$ and the requirement for insurance intermediaries and insurance undertakings to establish, implement and maintain specific conflicts of interest policy to be followed for the identification, prevention and management of such conflicts of interest. ${ }^{78}$ In particular, insurance intermediaries and insurance undertakings shall assess whether they, a relevant person or any person directly or indirectly linked to them by control, have an interest in the outcome of the insurance distribution activities, in the event such an interest: (a) is distinct from the customer's or potential customer's interest in the outcome of the insurance distribution activities; and (b) has the potential to influence the outcome of the distribution activities to the detriment of the customer. ${ }^{79}$

As for the conflict of interest policy, this should include the circumstances, related to the specific insurance distribution activity, which constitute or may give a rise to a conflict of interest which could damage the customers' interest, as well as the procedures to be followed and the measure to be adopted for the management of such conflicts. ${ }^{80}$ The policy should be assessed and periodically reviewed, on an at least annual basis, and amended in case of any deficiency. ${ }^{81}$ As regard to the insurance intermediaries, who are under a contractual obligation to conduct insurance distribution business exclusively with one or more insurance undertakings,

\footnotetext{
${ }^{76}$ Commission Delegated Regulation (EU) 2017/2359 of 21 September 2017 supplementing Directive (EU) 2016/97 of the European Parliament and of the Council with regard to information requirements and conduct of business rules applicable to the distribution of insurance-based investment products, http://data.europa.eu/eli/reg_del/2017/2359/oj.

${ }^{77}$ Article 3 of the Commission Delegated Regulation (EU) 2017/2359 of 21 September 2017 supplementing Directive (EU) 2016/97 of the European Parliament and of the Council with regard to information requirements and conduct of business rules applicable to the distribution of insurance-based investment products, http://data.europa.eu/eli/reg_del/2017/2359/oj.

${ }^{78}$ Article 4 of the Commission Delegated Regulation (EU) 2017/2359 of 21 September 2017 supplementing Directive (EU) 2016/97 of the European Parliament and of the Council with regard to information requirements and conduct of business rules applicable to the distribution of insurance-based investment products, http://data.europa.eu/eli/reg_del/2017/2359/oj.

${ }^{79}$ Article 3(2) of the Commission Delegated Regulation (EU) 2017/2359 of 21 September 2017 supplementing Directive (EU) 2016/97 of the European Parliament and of the Council with regard to information requirements and conduct of business rules applicable to the distribution of insurance-based investment products, http://data.europa.eu/eli/reg_del/2017/2359/oj.

${ }^{80}$ Article 4(2) of the Commission Delegated Regulation (EU) 2017/2359 of 21 September 2017 supplementing Directive (EU) 2016/97 of the European Parliament and of the Council with regard to information requirements and conduct of business rules applicable to the distribution of insurance-based investment products, http://data.europa.eu/eli/reg_del/2017/2359/oj.

${ }^{81}$ Article 7(1) and Recital 5 of the Commission Delegated Regulation (EU) 2017/2359 of 21 September 2017 supplementing Directive (EU) 2016/97 of the European Parliament and of the Council with regard to information requirements and conduct of business rules applicable to the distribution of insurance-based investment products, http://data.europa.eu/eli/reg_del/2017/2359/ oj.
} 
EIOPA has clarified that the conflict of interest policy remains a requirement under the responsibility of that intermediary. ${ }^{82}$

As in MiFID II, the disclosure of a conflict of interest should be avoided, except for the situations in which the organizational and administrative arrangements are insufficient for the prevention of risks of damage to the interests of the customer. ${ }^{83} \mathrm{In}$ such a case, the disclosure should be made on a durable medium and include sufficient detail, ${ }^{84}$ which means that it should provide a specific description of the conflict of interest in question, explain its general nature, sources, and associated risks for consumers, and state that the organizational and administrative arrangements established within the conflict of interest policy are not sufficient to ensure, with reasonable confidence, the prevention of such risks. ${ }^{85}$ Finally, the senior management of the insurance distributors should receive, at least annually, written reports on the situations in which a conflict of interest arose, and of these the insurance intermediary of undertaking should keep a record. ${ }^{86}$

\section{Product Oversight and Governance}

Article 25 of IDD sets Product Oversight and Governance ("POG") rules forth and the European Commission is empowered to adopt delegated acts to further specify the principles set out in this article, taking into account in a proportionate way the activities performed, the nature of the insurance products which were sold and the nature of the distributor. Thus, POG rules of the IDD are supplemented by Commission Delegated Regulation (EU) 2017/2358 of 21 September $2017,{ }^{87}$ which is based on the Technical advice provided by the EIOPA in February 2017.

\footnotetext{
${ }^{82}$ EIOPA (2018).

${ }^{83}$ Article 6(1) and Recital 5 of the Commission Delegated Regulation (EU) 2017/2359 of 21 September 2017 supplementing Directive (EU) 2016/97 of the European Parliament and of the Council with regard to information requirements and conduct of business rules applicable to the distribution of insurance-based investment products, http://data.europa.eu/eli/reg_del/2017/2359/ oj.

${ }^{84}$ Article 28(3) of the Directive (EU) 2016/97, op. cit.

${ }^{85}$ Article 6(2) and Recital 5 of the Commission Delegated Regulation (EU) 2017/2359 of 21 September 2017 supplementing Directive (EU) 2016/97 of the European Parliament and of the Council with regard to information requirements and conduct of business rules applicable to the distribution of insurance-based investment products, http://data.europa.eu/eli/reg_del/2017/2359/ oj.

${ }^{86}$ Article 7(2) and Recital 5 of the Commission Delegated Regulation (EU) 2017/2359 of 21 September 2017 supplementing Directive (EU) 2016/97 of the European Parliament and of the Council with regard to information requirements and conduct of business rules applicable to the distribution of insurance-based investment products, http://data.europa.eu/eli/reg_del/2017/2359/ oj.

${ }^{87}$ Commission Delegated Regulation (EU) 2017/2358 of 21 September 2017 supplementing Directive (EU) 2016/97 of the European Parliament and of the Council with regard to product oversight
} 
The Commission Delegated Regulation ${ }^{88}$ specifies the criteria and practical details for the application of POG rules, affirming that these rules are mainly addressed at manufacturers of insurance products and oblige them to maintain, operate and review a POG policy in order to ensure on a continuous basis that all insurance products marketed are appropriate for their specific target market. Insurance distributors have to support this by operating product distribution arrangements to ensure that they have all the information needed to sell the product in line with the POG policy set by the manufacturer. The POG rules are built around both the manufacturer and the distributor because the POG imposes separate duties to both of them, as well as general provisions. In addition, the same entity can play the role of manufacturer and distributor. ${ }^{89}$

The product oversight and governance (POG) rules in the IDD are a mere duplication of the rules in MiFID II, albeit with some slight differences. ${ }^{90}$ The set of rules on POG do not address a specific life insurance product. POG sets the duty for disclosure to the supervisory authority of the way in which the products are manufactured and the purposes actually pursued with these products by the insurance undertakings. ${ }^{91}$ Hence POG allows for the implementation of transparent and auditable product approval frameworks for new products the design of which is not compromised by profit or time pressures. With regards to "bancassurance", manufacturers have to provide assistance where sales were conducted through banks, without relying on the assumption that banking staff in sales functions had the necessary product knowledge.

For the life insurance sector, the rules on POG guarantee the design and distribution of products that satisfy the interests and needs of customers belonging to the target market and to whom those specific products are distributed, and safeguards the customer's protections to the point of sale as it forges the protection of customers with respect to poorly designed products. Manufacturers are the main recipients of POG rules. Both insurance undertakings and insurance intermediaries can qualify as manufacturers depending on the role they play in designing insurance products. ${ }^{92} \mathrm{In}$ the case of insurance undertaking playing a "passive" role or a non-exclusive role in the decision-making process, a distinction should be made whether the insurance undertaking has (i) outsourced the design activities or (ii) contributed to the design of the product with another entity.

and governance requirements for insurance undertakings and insurance distributors http://data. europa.eu/eli/reg_del/2017/2358/oj.

${ }^{88}$ Commission Delegated Regulation (EU) 2017/2358 of 21 September 2017 supplementing Directive (EU) 2016/97 of the European Parliament and of the Council with regard to product oversight and governance requirements for insurance undertakings and insurance distributors http://data. europa.eu/eli/reg_del/2017/2358/oj.

${ }^{89}$ Marano (2019).

${ }^{90}$ Marano (2019, 2020).

${ }^{91}$ Marano (2020) and Śliwiński and Marano (2020).

${ }^{92}$ See Article 25(1) of the Directive (EU) 2016/97 of the European Parliament and of the Council of 20 January 2016 on insurance distribution (recast) http://data.europa.eu/eli/dir/2016/97/oj. 
The IDD does not rule out that the co-manufacturing is done by two insurance undertakings without involving an insurance intermediary. This is the case of a life insurance product combining two different classes, e.g. unit-linked and assurance on survival to a stipulated age or on earlier death, each of them managed by one of the two insurance undertakings, whilst the product is distributed through the distribution channel selected by one of the undertakings.

Articles 9 and 10 of Commission Delegated Directive (EU) 2017/593 of 7 April $2016^{93}$ supplementing MiFID II could be a useful reference for the Member States as regulation on financial products deals with this issue. The IDD shall not affect a Member State's law in respect of insurance and reinsurance distribution activities pursued by insurance and reinsurance undertakings or intermediaries established in a third country and operating on its territory, provided that equal treatment is guaranteed to all persons carrying out insurance and reinsurance distribution activities on that market. ${ }^{94}$ The principle of equal treatment therefore requires national legislation to apply POG rules to products marketed in the country without taking into account the nationality of the manufacturer. Thus, the same principle can apply in the case of activities carried out by insurance entities based in third countries. ${ }^{95}$

\section{Impact of the IDD}

An essential focus of regulatory supervision is market conduct in insurance distribution, which is challenged by the IDD through the imposing of minimum advice quality and transparency standards for insurance distribution within EU member states. The IDD also implies that the member states may implement even stricter rules where necessary.

At first glance, it seems that the Europeanisation of the regulatory and supervisory system will lead to greater transparency for policyholders, new minimum standards for certain rules of cross-border business, more and better tools to supervise insurance intermediaries and general rules to sanction intermediaries that breach the provisions of the IDD, and ensure that insurance products with investment elements are protected in a similar way to other financial investment products in the EU. The new minimum harmonisation also equalises costs across various sales channels, largely through increased transparency to consumers, hopefully reducing barriers to the pursuit of fair insurance purchases. ${ }^{96}$ Overall, a solid regulatory framework can

\footnotetext{
${ }^{93}$ Commission Delegated Directive (EU) 2017/593 of 7 April 2016 supplementing Directive 2014/ $65 / \mathrm{EU}$ of the European Parliament and of the Council with regard to safeguarding of financial instruments and funds belonging to clients, product governance obligations and the rules applicable to the provision or reception of fees, commissions or any monetary or non-monetary benefits, http:// data.europa.eu/eli/dir_del/2017/593/oj.

${ }^{94}$ See Article 1(6) of the Directive (EU) 2016/97, op.cit.

${ }^{95}$ Marano (2019).

${ }^{96}$ Klumpes and Schuermann (2011).
} 
enhance the efficiency of insurance markets and lead to lower costs of insurance coverage. The U.S., where insurance is still regulated at the state level, might benefit from a unified regulatory framework. The new EU framework may thus serve as an example for the U.S.

Nevertheless, ensuring compliance with legal requirements implies bureaucratic costs, which are ultimately borne by the policyholders, and the implementation of the new IDD involves some major challenges for many EU countries. An important question to be addressed is whether this new EU-wide harmonisation regulation is an expedient and cost-efficient solution. The benefits of harmonised rules might not always outweigh the substantial costs of implementation, which will be different in each EU Member State. While such increased bureaucracy is unavoidably associated with a certain amount of costs involved in the process of meeting regulatory goals, "inefficient" regulation may lead to unnecessary costs. Inappropriate regulatory provisions might even result in useful insurance products disappearing from the market since potential policyholders are no longer willing to pay the resulting higher premiums. ${ }^{97}$ However, there are diverse and conflicting provisions in different areas in the U.S. as well, which might also result in additional costs (for instance, compliance costs) that are passed on to consumers and may lead to rising prices and possibly even to the disappearance of certain products from the market.

In the case of the new IDD, potentially high administrative costs for the involved parties in some Member States might arise, for instance through the introduction of the new online EU insurance distribution register. The design of such an online register, as well as its continued maintenance, may amount to additional costs for the insurance supervisor. A second example, for non-life insurance products is the Insurance Product Information Document ("IPID"), which will incur costs of developing the setting-up of the document technology infrastructure to manage the population of documents, as well as ongoing costs related to the circulation and renewal of IPIDs and other costs of record keeping. ${ }^{98}$

Another challenge is the alignment of new IDD requirements with other legal provisions, which might overlap, or be redundant or even contradict IDD requirements, and might ultimately lead to further unnecessary bureaucracy costs. Insufficiently harmonised parallel reform measures or lack of coordination between regulations circulated on different regulatory levels might result in a shortcoming of legal certainty and could bring about new risks and costs for the insurance industry. An example is the alignment of IDD requirements with MiFID II standards. In particular in the life insurance market, requirements have to be imposed to conform to MiFID II rules. ${ }^{99}$ Some other requirements such as the assessment to

\footnotetext{
${ }^{97} \mathrm{GDV}$ (2015), p. 19.

${ }^{98}$ Final Report on Consultation Paper no. 16/007 on draft Implementing Technical Standards concerning a standardised presentation format for the Insurance Product Information Document of the Insurance Distribution Directive (EIOPA-BoS-17/055), available at https://register.eiopa. europa.eu/Publications/Reports/IDD\%20Final\%20Report\%20on\%20draft\%20ITS\%20on\% 20IPID.pdf; Köhne and Brömmelmeyer (2018).

${ }^{99}$ Clifford Chance (2013) and Köhne and Brömmelmeyer (2018).
} 
ascertain the suitability and appropriateness of a product (Art. 30 IDD) might impose an additional administrative burden.

Moreover, the expected increase in reporting and disclosure requirements might involve excessive bureaucracy and it remains questionable whether the aspired goal of strengthened consumer protection can be reached. Not least, the additional administrative expenditure might imply a rise in premiums to the full detriment of consumers. The new regulatory changes do not take fully into account that some consumers are competent enough to research and purchase investment options and insurance products themselves. These consumers will prefer to buy insurance directly from insurance companies or via the Internet. With some insurance products disappearing from the marketplace for the above reasons, these consumers are clearly made worse off by some requirements of the new IDD. Additionally, future continuing professional training requirements might prove costly for insurance intermediaries. ${ }^{100}$ These costs will likely be passed on to consumers through fees or taxes. The additional costs to consumers may be worthwhile if increased education and transparency reduce the likelihood of bad advice by intermediaries. However, a potentially unintended consequence of the regulation is that stricter standards may lead insurance distributors to engage in defensive selling practices (i.e. recommending more insurance than is needed) in order to avoid professional liability claims. This motivation may be strengthened if the practice also leads to more commission income.

\subsection{Impact with Regards to the Life Insurance Sector}

The EU financial services regulation is increasingly cross-sectoral. The IDD introduces additional requirements for insurance-based investment products with the collective asset and the long term orientation being important differentiators of life insurance contracts and retail investment products. In relation to collective asset, ownership, retail investors individually purchase units or shares, whereas policyholders typically do not acquire the underlying assets of their life insurance contract but a contractual right towards the insurance undertaking. This contractual right materialises upon occurrence of the insured event such as death, disability, and longevity. The ownership of the underlying assets is held by the insurance undertaking which protects policyholders from the 'timing risk', i.e. when to buy and to sell. By concluding an insurance contract, the policyholder joins the community of insured, sharing all risks and costs based on the principles of solidarity and risk pooling. The policyholder's capital market and biometric risk, which are independent from each other, are pooled and coordinated by the insurance undertaking. As a result, policyholders receive twin benefits from investment and insurance protection under a single integrated contract. In relation to long term orientation, the holding

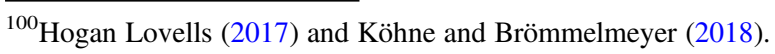


period of retail investment products is defined ex post and comprises often only a few years, including the option to exit at any time. By contrast, the holding period of life insurance contracts is defined ex ante and usually comprises several decades with restricted exit options. The long term orientation of life insurance is further underlined by the fact that customer intervention during the contract period is usually fairly limited, and contractual option(s) such as lump-sum payment or annuities can be exercised typically only at maturity.

Notwithstanding the differences outlined above, the IDD reflects an individual and short term approach. In relation to the correlation between product distribution and dealing on own account any potential conflicts of interest shall be assessed by taking into account whether the insurance distributor 'is likely to make a financial gain, or avoid a financial loss, to the potential detriment of the customer.

In contrast to the distribution of retail investment products, there is typically no correlation between the profit/loss made by the policyholder and the profit/loss made by the insurer. Therefore, it deserves further scrutiny whether, and how, this conflict of interest situation should be upheld in an insurance context. In relation to periodic assessments, insurance distributors shall inform their customers whether a periodic assessment of the suitability of the insurance-based investment products will be carried out. ${ }^{101}$ However, life insurance contracts are characterised by a long term orientation that precludes short-term customer intervention. Quite the contrary, ex post changes to insurance contracts, such as surrender or withdrawal, mostly imply disadvantages with regards to costs and fiscal treatment.

In the customer's best interest, the stable, long term character of life insurance should not be undermined by artificial volatility caused by short-term customer intervention. In relation to periodic reports, at least annually, the customer has to be informed about any 'transactions' that have been undertaken on his behalf. In an insurance context, the wording 'on behalf' seems unsuitable as any investment activity by insurers is typically carried out on behalf of the entire community of insured. In the insurance sector, this issue could be resolved by specifying that this provision only applies to 'transactions made upon explicit request of the individual customer.' 102

\subsection{Assessment of Suitability}

The IDD provides specific conduct of business rule, not derived from MiFID IIregime, known as the demands and needs test. The scope of this test is not prescribed in the IDD or the Delegated Regulation ${ }^{103}$ and is subject to national implementation. However, EIOPA provided some guidance regarding minimum

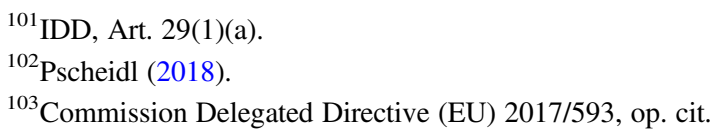


expectations for this test and how it may relate to the assessment of suitability. ${ }^{104}$ Recital 7 of Delegated Regulation 2017/2359 ${ }^{105}$ clarifies that the assessments of suitability and appropriateness are without prejudice to the obligation, for insurance intermediaries and insurance undertakings, to consider and specify, prior to the conclusion of any insurance contract, on the basis of information obtained from the customer, and the demands and needs of that customer.

The demands and needs test provides a protection for customers to avoid cases of mis-selling (Recital 44, IDD) and it applies to all insurance contracts, not just IBIPs. Article 30, IDD applies "without prejudice" to the demands and needs test as covered by Article 20(1), IDD. The demands and needs test has to be performed in any event prior to the conclusion of the contract and is distinct from the suitability assessment in advised cases, and the suitability assessment can also be provided at any time during the customer relationship. The assessment of demands and needs is required whether or not advice is being provided and the specifying of the demands and needs would not amount to a suitability assessment. Depending on the national implementation, where advice is being provided, the demands and needs test and assessment of suitability could be seen as a continuum, rather than as a break.

The main information concerning the customer's needs, typically includes, for example, personal information (age, profession, place of residence etc.) or the information particularly linked to the type of product requested. This information should enable the insurance intermediary or insurance undertaking to assess whether certain products can be offered or not according to their capacity of meeting the demands and needs of the customer. This could lead to a selection of a range of comparable products for consideration during the suitability assessment where advice is being given or during the appropriateness assessment where no advice is given.

Where the customer is provided with advice the information, which will be obtained by the insurance intermediary or the insurance undertaking, will need to include other more specific and detailed elements, like the customer's financial situation, including their ability to bear losses, their investment objectives, including their risk tolerance, and other correlated information. Under the IDD and the Delegated Regulation, ${ }^{106}$ the provisions concerning the assessment of suitability and appropriateness are almost identical to the corresponding provisions under MiFID II and its specific Delegated Regulation. ${ }^{107}$ In particular, the suitability assessment requires that the insurance intermediary or undertaking, in the case of sales with advice, gathers information about their client's knowledge, experience,

\footnotetext{
${ }^{104}$ EIOPA (2018).

${ }^{105}$ Commission Delegated Regulation (EU) 2017/593 op.cit.

${ }^{106}$ Articles 9-19 of the Commission Delegated Regulation (EU) 2017/2359 op.cit.

${ }^{107}$ Commission Delegated Regulation (EU) 2017/565 of 25 April 2016 supplementing Directive 2014/65/EU of the European Parliament and of the Council as regards organisational requirements and operating conditions for investment firms and defined terms for the purposes of that Directive, available at http://data.europa.eu/eli/reg_del/2017/565/oj.
} 
investment objective and risk tolerance-in order to recommend to the client the IBIPs that are best aligned with the client's profile, ${ }^{108}$ which means that it meets the client's investment objectives, risk tolerance, financial situation and that its nature and characteristics are adequate in respect to the client's knowledge and experience. $^{109}$

The insurance intermediary or undertaking should adopt measures to ensure that the information collected about the clients is reliable, and communicate them that the suitability assessment is performed in their best interest. ${ }^{110}$ It should then provide the customer with the so-called 'suitability statement', which includes an outline of the advice given, as well as information about how the recommendation meets the customer's investment objectives, risk tolerance, financial situation, knowledge and experience. $^{111}$

The appropriateness requirement provides that, in the event of sales requiring no advice, the insurance intermediary or insurance undertaking gathers information on the client to assess if the product or services offered or demanded were appropriate for the customer. ${ }^{112}$ In the event the product is deemed not appropriate for the customer, the insurance intermediary or insurance undertaking should warn the customer or potential customer. ${ }^{113}$ Article 19(3) of Delegated Regulation 2017/ 2359 contains requirements for records to be kept in relation to the appropriateness assessment, in particular regarding the result of the assessment, warnings given to the customer and storage in an accessible manner for future reference. As under MiFID II, this assessment is not required concerning non-complex products as defined by MiFID II. ${ }^{114}$ However, due to the specific structures of insurance products, the Commission Delegated Regulation under IDD provides, among the criteria for non-complex IBIPs, an additional condition concerning products including a specific guarantee. ${ }^{115}$

Moreover, the insurance intermediary or insurance undertaking should establish a record of documents agreed with the customer containing rights and obligations of the parties, as well as other terms related to the provision of services to the customer. The customer should also be provided with periodic reports on the service, which include a number of communications proportionate to the type and complexity of the IBIP involved. ${ }^{116}$

\footnotetext{
${ }^{108}$ Article 30(1) of the IDD.

${ }^{109}$ Article 9(2) of the Commission Delegated Regulation (EU) 2017/2359 op.cit.

${ }^{110}$ Article10 and 11 of the Commission Delegated Regulation (EU) 2017/2359 op.cit.

${ }^{111}$ Article 14(1) of the Commission Delegated Regulation (EU) 2017/2359 op. cit.

${ }^{112}$ Article 30(2) of IDD and Article 14 of the Commission Delegated Regulation (EU) 2017/2359 op. cit.

${ }^{113}$ Noussia and Siri (2019).

${ }^{114}$ Article 30(3) IDD and 25(4)(a) MiFID II.

${ }^{115}$ Article 16(a) of the Commission Delegated Regulation (EU) 2017/2359.

${ }^{116}$ Articles 30(4) and (5) IDD.; Noussia and Siri (2019).
} 


\section{A Comparison of the EU and U.S. Insurance Distribution Regulatory Regime}

Whilst the IDD attempts to reduce cross-sectoral and cross-border inconsistencies by establishing a more uniform regulatory framework in the European insurance market, via the introduction to insurance distribution systems of minimum quality standards and disclosure requirements to insurance distribution systems, "the U.S. insurance regulation mostly continues to be the purview of state government, leading to cumbersome and conflicting provisions as well as higher compliance costs". 117

The new IDD attempts to reduce cross-sectoral and cross-border inconsistencies by establishing a more uniform regulatory framework in the European insurance market. For this purpose, minimum quality standards and disclosure requirements are introduced to insurance distribution systems. In contrast, "U.S. insurance regulation mostly continues to be the purview of state government, leading to cumbersome and conflicting provisions as well as higher compliance costs". ${ }^{118}$

"In the US, insurance regulation is almost entirely the responsibility of the individual states, the individual state insurance commissioners and the National Association of Insurance Commissioners (NAIC). The NAIC drafts the model insurance laws, however the NAIC Model Acts are mainly advisory tools. The primary body of law applied to insurance intermediaries is the Producer Licensing Model Act (PLMA)". 119

"The most striking difference between the PLMA and the IDD is that the PMLA is written from the perspective of the individual U.S. state legislators constitutes a suggestion of an advisory body whereas the IDD is a mandatory Directive". ${ }^{120}$

The IDD also enhances standards related to information requirements and conduct of business rules (Chapter V, IDD). The IDD marks another step in further harmonising the European market for insurance regulation and creating a level playing field. It imposes new requirements which broaden the scope of regulatory oversight of insurance distribution channels as well as imposing new constraints on business conduct, including continuing professional training for sales people and compensation disclosure to enhance market conduct regulation. "Chapter V of the IDD delineates the information requirements for intermediaries, and the rules applicable to their business conduct. Section 12 of the PLMA lists prohibited actions which can lead to an insurance intermediary's license revocation and a civil penalty. Despite that the IDD language is written in a prescriptive manner and the PLMA is written in a proscriptive manner, there are some similarities." ${ }^{121}$ Article 17 of the

\footnotetext{
${ }^{117}$ Defever (2021), p. 198; Hofmann et al. (2018).

${ }^{118}$ Defever (2021), p. 198; Hofmann et al. (2018).

${ }^{119}$ Defever (2021), p. 198.

${ }^{120}$ Defever (2021), p. 200.

${ }^{121}$ Defever (2021), p. 201.
} 
IDD requires that insurance distributors always act honestly, fairly and professionally in accordance with the best interests of their customers. Section 12 A. (8) of the PLMA forbids an insurance producer from using fraudulent, coercive, or dishonest practices, or demonstrating incompetence, untrustworthiness or financial irresponsibility in the conduct of business. "What is strikingly missing from the PLMA is the requirement that U.S. insurance intermediaries act with the best interests of their customers, as is required of European intermediaries. Another requirement present in the IDD that is glaringly absent from the PLMA is that marketing be "fair, clear, and not misleading." 122 The PLMA places only two restrictions on the remuneration of insurance producers-one, that a producer must be licensed in order to receive commissions, and two, that the producer must disclose a compensation agreement with an insurer if the producer is also receiving compensation from the customer. ${ }^{123}$ In contrast, the IDD mandates that Member States shall ensure that distributors and their employees are not remunerated in a way that conflicts with their duties to act in accordance with the best interest of their customers; ${ }^{124}$ that they reveal business holdings that create conflicts; ${ }^{125}$ that they reveal whether advice is based on fair and personal analysis or not, or whether there is exclusivity with an insurance company; ${ }^{126}$ and that they reveal the nature of remuneration received, i.e. fee, commission, or other, and the amount, and whether it ties to employee remuneration."127

In terms of regulatory scope, the IDD allows insurance intermediaries to sell products across multiple EU Member States where previously parity did not always exist. The U.S. has attempted to provide some kind of uniformity in cross-state producer licencing with the GLB Act (passed in 1999) ${ }^{128}$ and NARAB II Regulation (passed in 2015). ${ }^{129}$ Additionally, the IDD introduces minimum requirements for all distributors of insurance and reinsurance policies, including direct sales, agents, brokers and others, to comply with new disclosure and training requirements to enhance consumer protection independent of the distribution channel. Nevertheless, the IDD is a minimum harmonisation Directive leaving the Member States with the opportunity to implement even stricter rules. U.S. intermediary regulation is not uniform between retail, wholesale and reinsurance sales. Individual state and national laws govern these transactions separately, which may impact consumer protection measures differently, depending on the distribution channel.

The IDD requires insurance distributors to be registered with a competent authority in their home member state (Art. 3(1) IDD), and member states have to implement an online EU insurance distribution register and ensure that a single

${ }^{122}$ IDD Art. 17, 2.

${ }^{123}$ Defever (2021), pp. 201-202.

${ }^{124}$ IDD Art. 17, 3.

${ }^{125}$ IDD Art. 19, 1. (a) and (b).

${ }^{126}$ IDD Art. 19, 1. (c).

${ }^{127}$ IDD Art. 19, 1. (d), (e), 2., and 4.; Defever (2021), pp. 201-202.

${ }^{128}$ Gramm-Leach-Bliley Act (GLBA), also known as the Financial Services Modernization Act of 1999, (Pub.L. 106-102, 113 Stat. 1338, enacted November 12, 1999).

${ }^{129}$ NARAB II Regulation, Public Law No: 114-1 (01/12/2015). 
information point exists. ${ }^{130}$ Similarly, in the U.S. all intermediaries have to obtain a licence (depending on the type of insurance, e.g., a Property and Casualty licence, or a Life, Accident and Health licence) in order to sell insurance.

According to the IDD, a basic level of advice quality has to be guaranteed, and continuing education of insurance intermediaries is required, but Member States may impose additional standards on producers. The NARAB Board in the U.S. imposes minimum continuing professional training standards for licenced producers, but individual states may vary their re-licencing standards for the intermediaries licenced there. Many states require a portion of continuing education to focus on ethics, but otherwise licencees may choose their own training so that the actual training may lead to considerable differences regarding the knowledge and competency of intermediaries.

With regards to information requirements and conduct of business the IDD provides strengthened consumer protection and requires from the intermediary to inform the consumer of any potential conflicts of interest before the insurance contract is finalised (e.g., Art. 18 IDD). These disclosure requirements exceed any standard disclosures provided by U.S. insurance intermediaries. As part of this disclosure, the IDD imposes additional standards on insurance producers related to compensation, i.e. they need disclose to the consumer the amount of compensation they receive for the sale of the insurance product (Art. 19 IDD); previously, this compensation disclosure requirement varied by EU member state. In the U.S. there is no standard requirement to disclose producer compensation, but again this varies by state, leaving consumers with a certain lack of clarity regarding their rights. ${ }^{131}$

Moreover, in the EU, compensation of insurance distributors may be a commission paid by the insurer, a fee paid by the insured, or any other remuneration within the contract, but always provided that this does not conflict with the distributor's duties to act in the best interest of its customers (Art. 17(3) IDD). In addition, in the U.S. there is not just one standard compensation scheme for insurance intermediaries: compensation varies with regard to the type of insurance sold and the nature of the relationship between the producer and insurer. Beside the standard commissions, intermediaries can also receive a contingent commission.

Other new IDD disclosure requirements to improve consumer protection are requirements that are placed on insurance distributors in relation to advice and how this advice is provided. Depending on the complexity of the insurance product and consumer type, there is a requirement to specify the demands and needs of the customer and provide objective information in a comprehensible format. For certain non-life insurance products this has to be summarised in the IPID, which mandates policy-level disclosures (e.g., coverages, exclusions and restrictions) to the insured. In the U.S. there is no comparable standard document, and requirements vary by state. Whether intermediaries have a duty to advise their client also depends on the state.

\footnotetext{
${ }^{130}$ Köhne and Brömmelmeyer (2018) and Hogan Lovells (2017).

${ }^{131}$ Scism (2012) and Köhne and Brömmelmeyer (2018).
} 
Furthermore, the IDD requires insurance undertakings to comply with new POG requirements to ensure certain suitability for the defined target market and a focus on consumer protection measures. In addition, consistency between Member States is ensured.

Similar to non-life insurance products, the IDD also enhances the information and disclosure requirements for IBIPs. Additionally, insurance intermediaries must assess the suitability and appropriateness of the product for the customer (Art. 30 IDD), which again highlights the increased focus on consumer protection in the $\mathrm{EU}$ and aims to improve the alignment and consistency between the regulation of financial and insurance markets. In the U.S., life insurance contracts may be subject to regulation by (1) the Securities and Exchange Commission if the contracts qualify as securities that are not exempt under the U.S. federal securities laws, and (2) by the U.S. Department of Labor if they are offered in connection with employee benefit plans.

While insurance regulation in the U.S. continues to be the purview of state government, some federal regulation and standardised practices affect insurance distribution systems nationally. Most notably, the NARAB II regulation (passed in $2015)^{132}$ provides reciprocity between states for licenced insurance providers. However, insurance regulation in the EU appears to consistently move towards more harmonisation across Member States. The IDD marks another change in the divide between EU regulatory uniformity and U.S. regulatory dispersion and can maybe set an example for the U.S.

An essential focus of regulatory supervision is market conduct in insurance distribution, which is challenged by the IDD through the imposing of minimum advice quality and transparency standards for insurance distribution within EU member states. The IDD also implies that the member states may implement even stricter rules where necessary.

At first glance, it seems that the Europeanisation of the regulatory and supervisory system will lead to greater transparency for policyholders, new minimum standards for certain rules of cross-border business, more and better tools to supervise insurance intermediaries and general rules to sanction intermediaries that breach the provisions of the IDD, and ensure that insurance products with investment elements are protected in a similar way to other financial investment products in the EU. The new minimum harmonisation also equalises costs across various sales channels, largely through increased transparency to consumers, hopefully reducing barriers to the pursuit of fair insurance purchases. ${ }^{133}$ Overall, a solid regulatory framework can enhance the efficiency of insurance markets and lead to lower costs of insurance coverage. The U.S., where insurance is still regulated at the state level, might benefit from a unified regulatory framework. The new EU framework may thus serve as an example for the U.S.

\footnotetext{
${ }^{132}$ NARAB II Regulation, Public Law No: 114-1 (01/12/2015).

${ }^{133}$ Klumpes and Schuermann (2011).
} 
"The primary difference between the IDD and the PLMA is that the IDD is mandatory and the PLMA is voluntary. Due to its advisory nature, the PMLA has been inconsistently adopted and inconsistently enforced. The bodies of regulations applying to insurance producers remain in a piecemeal state, and the PMLA has done very little to close the gaps". ${ }^{134}$

"The takeaway for EU Member States should be that uniformity will not be achieved until and unless they adopt and apply the mandatory penalties provided in the IDD and achieve a sufficient level of transparency to aid consumers in avoiding bad actors, and to act as a deterrence to producers. The IDD's more prescriptive, rules-based insurance regulations will be the first of their kind to be applied across such a wide and diverse territory like the EU Member States." 135

The benefits of the new IDD can only be evaluated after introduction of the Directive when a direct comparison with the status quo becomes possible. It seems that some of the envisaged provisions include redundancies for several Member States and will lead to duplicate requirements, which may make implementation even more complicated. However, some important questions remain: Do consumers feel better informed? Do consumers make better decisions? Can important losses be prevented? An important challenge is that the insurance industry in Europe might fail to recognise the integration of borderless markets. As argued by Schiro ${ }^{136}$ many insurance markets continue to transcend borders such that national regulation may increasingly spill over from one local jurisdiction to another, thereby leading to the risk of conflicting regulations.

Nevertheless, the IDD will, despite the challenges of implementation, likely help to establish a harmonisation of European insurance markets through more uniform standards and regulation. This will reduce legal uncertainties and facilitate fair competition between insurance companies and intermediaries in different EU Member States. Notably, consumer protection across all financial sectors can be improved by aligning the regulatory system for insurance and financial markets. All in all, the new IDD will enhance the efficiency of European insurance markets. Through more uniform and consistent regulation, in conjunction with extended transparency requirements, it can ensure that consumers throughout the EU are equally well protected. Therefore, these more uniform regulations could set an example for dispersion in U.S. insurance regulation.

\footnotetext{
${ }^{134}$ Defever (2018); Defever (2021), p. 215.

${ }^{135}$ Defever (2018).

${ }^{136}$ Schiro (2006) and Köhne and Brömmelmeyer (2018).
} 


\section{Conclusions}

At the age of transparency, the IDD has a direct application in the life insurance sector in relation to the improvement of quality of products delivered to the customers. ${ }^{137}$ The IDD acts as a minimum harmonisation directive, allowing stricter rules at national level to be imposed. It promotes transparency and the insured's customer's protection and in doing so accomplishes a large harmonization impact and effect in the insurance industry overall, in line with the view for a single harmonised market.

The requirements set by the IDD for life insurance products require a minimum necessary knowledge of IBIPs, of the various financial risks, of the life policies and of the organisation and benefits guaranteed by the various investments products. Insurance distributors need always act honestly, fairly and professionally in accordance with the best interests of their customers and disclose their general personal information and redress and opt out procedures so as to enhance transparency. A duty to advise and provide a personalised recommendation as needed also exists. The IDD allows insurers to accept and retain fees, commissions or any monetary and non-monetary benefits from third parties, and particularly from issuers or product providers regarding the distribution of an IBIP as long as the payment of such remuneration does not impact negatively the provision of insurance and does not impair the distributor's professional capacity and obligations. The IDD also introduces additional requirements for IBIPs with the collective asset and the long term orientation being important differentiators of life insurance contracts and retail investment products.

Overall, following the wave of other regulatory changes, such as MiFID II and PRIIPS Regulation, ${ }^{138}$ the IDD intends to strengthen consumer protection, improve the competitive landscape of the European insurance industry, and reduce crosssectoral inconsistencies. The IDD also introduces product oversight and governance requirements similar to MiFID II. In relation to assessing the suitability and appropriateness of this is conducted by insurance companies that provide advice to customers on IBIPs so as to enable them to recommend to the customer or potential customer the IBIPs that are suitable for that person. IBIPs are an essential feature of insurance industry. However, it has not always been easy to make them widely known to the wider public due to the slow opening of the market for financial services within the EU. IDD will hopefully provide a more harmonized and more efficient legal framework, fostering the convergence of investor protection within the financial sectors as a whole. ${ }^{139}$

\footnotetext{
${ }^{137}$ Śliwiński and Marano (2020).

${ }^{138}$ Regulation (EU) No 1286/2014 of the European Parliament and of the Council of 26 November 2014 on key information documents for packaged retail and insurance-based investment products (PRIIPs), http://data.europa.eu/eli/reg/2014/1286/oj.

${ }^{139}$ Noussia and Siri (2019).
} 
To be able to make a critical assessment of the IDD, the individual rules and regulations must be evaluated in terms of their sense and appropriateness. As far as the IBIPs are concerned, it is problematic that the scope of their regulation remains doubtful and that apart from the unresolved problem of classifying existing life insurance products in relation to IBIPs, the IDD also remains vague in terms of the further distinction between complex and non-complex IBIPs, which renders the application of IDD and IDD-related provisions even more complicated. ${ }^{140}$

The legislator provides for an IDD evaluation to be carried out after 3 years. However, this is questionable and difficult to achieve due to a lack of market-wide costs. Hence, future research will be required with regards to the individual rules and regulations so as to achieve a verification of the level of target achievement at before and at an early stage from the introduction of the rules, and thereafter at certain intervals. $^{141}$

\section{References}

Audigier I (2020) Insurance Distribution Directive and cross-border activities by insurance intermediaries in the EU. In: Marano P, Noussia K (eds) Insurance Distribution Directive: promises and reality. Springer, Cham

Colaert V (2015) European banking, securities and insurance law: cutting through sectoral lines? Common Market Law Rev 52:1579-1616

Cummins J et al (2017) Competition, efficiency and soundness in European life insurance markets. J Financ Stab 28:66-78

Das MUS, Podpiera R, Davies N (2003) Insurance and issues in financial soundness, IMF Working Papers: Working Paper No. 03/138. International Monetary Fund, Washington, D.C.

De Maesschalck N (2017) The Insurance Distribution Directive: what does it change for intermediaries and for others? In: Marano P, Siri M (eds) Insurance regulation in the European Union. Palgrave Macmillan, Cham

Defever KM (2018) Comparative analysis of European Union and United States insurance law systems - with emphasis on consumer protection law, (2018). Eur J Commer Contract Law 10:9-27

Defever KM (2021) Enaction of Chapter VII of the Insurance Distribution Directive: what can Member States learn from the enforcement failures of the United States? In: Marano P, Noussia $\mathrm{K}$ (eds) Insurance Distribution Directive. AIDA Europe Research Series on Insurance Law and Regulation, vol 3. Springer, Cham. https://doi.org/10.1007/978-3-030-52738-9_9

Doff R (2008) A critical analysis of the solvency II proposals. Geneva Papers Risk and Insur Iss Practice 33(2):193-206

Eling M, Schmeiser H, Schmit JT (2007) The solvency II process: overview and critical analysis. Risk Manag Insur Rev 10(1):69-85

Gaganis C, Pasiouras F (2013) Financial supervision regimes and bank efficiency: international evidence. J Bank Financ 37(12):5463-5475

GDV (2015) Regulation in the insurance industry: opportunities and challenges from an economic perspective. Economic issues and analyses (7). German Insurance Association (GDV), Berlin

\footnotetext{
${ }^{140} \mathrm{Köhne}$ and Brömmelmeyer (2018).

${ }^{141}$ Köhne and Brömmelmeyer (2018).
} 
Hofmann A, Neumann JK, Pooser D (2018) Plea for uniform regulation and challenges of implementing the new Insurance Distribution Directive. Geneva Paper Risk Insur Iss Pract 43:740-769. https://doi.org/10.1057/s41288-018-0091-6

Kern (2018) Marketing, sale and distribution. Mis-selling of financial product. A study requested by the ECON Committee, Directorate-General for Internal Policies PE 618.996

Klumpes PJM, Schuermann S (2011) Corporate, product and distribution strategies in the European life insurance industry. Geneva Papers Risk Insur Iss Pract 36(1):50-75

Köhne P, Brömmelmeyer C (2018) The new insurance distribution regulation in the EU-a critical assessment from a legal and economic perspective. The Geneva papers on risk and insurance issues and practice. Palgrave Macmillan, The Geneva Association, vol 43(4), pp 704-739

Lorent B (2008) Risks and regulation of insurance companies: is solvency II the right answer?, Working Papers CEB 08-007. RS, Université Libre de Bruxelles

Malinowska K (2018) Customer's best interest as a rule in insurance contracts, considerations against new regulations on insurance distribution. In: Malinowska K, Tarasiuk A (eds) Insurance challenges of Anno Domini 2018. Publikacja jubileuszowa AIDA, Warszawa, p 57

Marano P (2017) Sources and tools of the insurance regulation. In: Marano P, Siri M (eds) Insurance regulation in the European Union: solvency II and beyond. Palgrave Macmillan, London, pp 5-30

Marano P (2019) The product oversight and governance: standards and liabilities. In: Marano P, Rokas I (eds) Distribution of insurance-based investment products. The EU regulation and the liabilities. Springer, Berlin, pp 59-96

Marano P (2020) The contribution of Product Oversight and Governance (POG) to the single market: a set of organizational rules for business conduct. In: Marano P, Noussia K (eds) Insurance Distribution Directive: a legal analysis. Springer, Berlin

Martinez L, Marano P (2020) The new EU rules on insurance customer/policyholder protection viewed against the NAIC model acts. Global Jurist 20190039:1934-2640. https://doi.org/10. 1515/gj-2019-0039. ISSN (Online)

Noussia K, Siri M (2019) The legal regime and the relevant standards. In: Marano P, Rokas I (eds) Distribution of insurance-based investment products. The EU regulation and the liabilities. Springer, Berlin, pp 28-56

Paś I (2020) Ensuring the customer's best interest in the Polish insurance market. In: Marano P, Noussia K (eds) Insurance Distribution Directive: promises and reality. Springer, Berlin

Petsch V (2019) The necessity for regulating the insurance market considering the implementation of the IDD (September 12, 2019). 2019 ENTRENOVA conference proceedings. SSRN: https:// ssrn.com/abstract $=3490486$

Pscheidl D (2018) Implementing IDD across the EU-first findings and the way forward. ERA Forum 19:205-217. https://doi.org/10.1007/s12027-018-0524-5

Schiro J (2006) External forces impacting the insurance industry: threats from regulation. Geneva Papers Risk Insur Iss Pract 31(1):25-30

Scism L (2012) Insurance fees, revealed. Wall Street J, 30 Mar 2012

Śliwiński A, Marano P (2020) Innovation in life insurance: the economic landscape and the Insurance Distribution Directive. In: Borda M, Grima S, Kwiecien I (eds) Life insurance in Europe. Risk analysis and market challenges. Springer, Berlin

\section{Legislation}

Commission Delegated Regulation (EU) 2017/2358 of 21 September 2017 supplementing Directive (EU) 2016/97 of the European Parliament and of the Council with regard to product oversight and governance requirements for insurance undertakings and insurance distributors. http://data.europa.eu/eli/reg_del/2017/2358/oj 
Directive (EU) 2016/97 of the European Parliament and of the Council of 20 January 2016 on insurance distribution (recast). http://data.europa.eu/eli/dir/2016/97/oj

Directive 2009/138/EC of the European Parliament and of the Council of 25 November 2009 on the taking-up and pursuit of the business of Insurance and Reinsurance (Solvency II). http://data. europa.eu/eli/dir/2009/138/oj

Directive 2014/65/EU of the European Parliament and of the Council of 15 May 2014 on markets in financial instruments and amending Directive 2002/92/EC and Directive 2011/61/EU. http:// data.europa.eu/eli/dir/2014/65/oj

European Commission (2016) Commission Delegated Regulation of 30 June 2016 supplementing Regulation (EU) No 1286/2014 of the European Parliament and of the Council on key information documents for packaged retail and insurance based investment products (PRIIPs) by laying down regulatory technical standards with regard to the presentation, content, review and revision of key information documents and the conditions for fulfilling the requirement to provide such documents $(\mathrm{C}(2016) 3999$ final $)$

Regulation (EC) No 593/2008 of the European Parliament and of the Council of 17 June 2008 on the law applicable to contractual obligations (Rome I). http://data.europa.eu/eli/reg/2008/593/oj

Regulation (EU) No 1286/2014 of the European Parliament and of the Council of 26 November 2014 on key information documents for packaged retail and insurance-based investment products (PRIIPs). http://data.europa.eu/eli/reg/2014/1286/oj

\section{Documents}

CII: Policy Briefing: Implementing the Insurance Distribution Directive: key provisions and analysis. March 2018, https://www.cii.co.uk/media/7775189/cii-policy-briefing-idd-implemen tation-22march2018.pdf

Clifford Chance (2013) How to distribute insurance products in the current regulatory environment. February 2013, London, https://www.cliffordchance.com/briefings/2013/02/how_to_distribu teinsuranceproductsinth.html

EIOPA (2017) Technical Advice on possible delegated acts concerning the Insurance Distribution Directive, 1/2/2017, EIOPA-17/048. https://eiopa.europa.eu/Publications/Consultations/EIOPA \%20Technical\%20Advice\%20on\%20the\%20IDD.pdf

EIOPA (2018) Q and A on Regulation - Answers - Commission Implementing Regulations laying down Implementing Technical Standards, (EU) 2017-2359 Info requirements and conduct of business rules applicable, published on: July 16 2018. https://eiopa.europa.eu/Pages/Guidelines/ Q-and-A-on-Regulation-Answers-Commission-Imple0menting-Regulations.aspx

G-20 Leaders (2008) Washington, D.C. Summit—Leaders' Statement. http://www.nytimes.com/ 2008/11/16/washington/summit-text.html?pagewanted=all

Hogan Lovells (2017) Insurance Distribution Directive. . .one year to go, http://viewer.zmags.com/ publication/f42cbb3c\#/f42cbb3c/1

OECD (1998) Competition and related regulation issues in the insurance industry. http://www. oecd.org/regreform/sectors/1920099.pdf. 04 Apr 2019

Practice Note (2020) Insurance Distribution Directive (IDD), Practical Law UK Practice Note 4-544-5805, Thomson Reuters. https://uk.practicallaw.thomsonreuters.com/4-544-5805? transitionType $=$ Default\&contextData $=($ sc.Default $) \&$ firstPage $=$ true\#co_anchor_a675177 
Open Access This chapter is licensed under the terms of the Creative Commons Attribution 4.0 International License (http://creativecommons.org/licenses/by/4.0/), which permits use, sharing, adaptation, distribution and reproduction in any medium or format, as long as you give appropriate credit to the original author(s) and the source, provide a link to the Creative Commons licence and indicate if changes were made.

The images or other third party material in this chapter are included in the chapter's Creative Commons licence, unless indicated otherwise in a credit line to the material. If material is not included in the chapter's Creative Commons licence and your intended use is not permitted by statutory regulation or exceeds the permitted use, you will need to obtain permission directly from the copyright holder. 